\title{
PENGARUH KINERJA KEUANGAN, DPK DAN JUMLAH SBI TERHADAP PENYALURAN KREDIT PERBANKAN (Studi Pada Bank BUMN Yang Terdaftar di BEI Periode 2009 - 2018)
}

\author{
Tieka Trikartika Gustyana \\ Prodi S1 Manajemen Bisnis Telekomunikasi dan Informatika, Fakultas Ekonomi dan Bisnis \\ Universitas Telkom, Indonesia \\ thieqa.gustyana80@gmail.com \\ Sasdalia Nova Diena \\ Prodi S1 Manajemen Bisnis Telekomunikasi dan Informatika, Fakultas Ekonomi dan Bisnis \\ Universitas Telkom, Indonesia \\ sasdalianova@gmail.com
}

\begin{abstract}
Abstrak
Fungsi perbankan sebagai lembaga intermediasi akan memunculkan kegiatan bagi bank untuk menghimpun dana berlebih di masyarakat dan menyalurkan kembali dana tersebut dalam bentuk kredit. Nantinya aktivitas penyaluran kredit perbankan akan dipengaruhi oleh beberapa faktor yaitu dana pihak ketiga (DPK), capital adequacy ratio (CAR), return on asset (ROA), non performing loan (NPL) dan jumlah sertifikat Bank Indonesia (SBI). Berdasarkan hasil penelitian diperoleh penjelasan bahwa secara simultan DPK, CAR, ROA, NPL dan jumlah SBI berpengaruh terhadap penyaluran kredit perbankan. Sedangkan secara parsial DPK dan CAR berpengaruh terhadap penyaluran kredit perbankan, sementara ROA, NPL dan jumlah SBI tidak berpengaruh terhadap penyaluran kredit perbankan.
\end{abstract}

Kata kunci: Penyaluran kredit, DPK, CAR, ROA, NPL dan jumlah SBI.

\section{Abstract}

The function of the banking sector as an intermediary will lead to activities for banks to raise excess funds in the community and redistribute the funds in the form of credit. Bank lending activities will be influenced by several factors, namely third party funds (DPK), capital adequacy ratio (CAR), return on assets (ROA), non-performing loans (NPLs) and the number of Bank Indonesia certificates (SBI). Based on the results of the study explained that simultaneously DPK, CAR, ROA, NPL and the number of SBI affect the distribution of bank credit. While partially DPK and CAR affects bank lending, while ROA, NPL and the number of SBI does not affect bank lending.

Keywords: Bank lending, DPK, CAR, ROA, NPL and the number of SBI. 
Lembaga perbankan memiliki sebuah fungsi yakni fungsi intermediasi. Fungsi ini menjadikan bank sebagai badan usaha yang menghimpun dana berlebih yang ada di masyarakat dan menyalurkan kembali dana yang telah dihimpun dalam bentuk penyaluran kredit.

Terdapat beberapa macam penyaluran kredit yang dilakukan oleh bank. Beberapa di antaranya merupakan kredit sindikasi dan kredit usaha rakyat (KUR). Kredit sindikasi merupakan kredit yang diberikan oleh lebih dari satu kreditur (bank) kepada debitur. Sasaran dari kredit sindikasi adalah proyek yang membutuhkan dana dalam jumlah besar. Proyek dengan jumlah dana yang besar banyak dibutuhkan pada proyek pembangunan infrastruktur maupun manufaktur. Di tahun 2018 terdapat banyak proyek pembangunan infrastruktur maupun manufaktur yang salah satu di antaranya adalah proyek Light Rail Transit (LRT). Proyek ini didanai oleh enam bank kreditur dengan tiga bank di antaranya merupakan bank BUMN yaitu Bank Mandiri, BNI dan BRI, dengan total jumlah kredit mencapai Rp.18,1 triliun (detikfinance, 2017).

Aktivitas penyaluran kredit perbankan sangat mendapat dukungan dari pemerintah.
Hal ini dikarenakan secara tidak langsung penyaluran kredit perbankan nantinya akan ikut berpartisipasi dalam menggerakan roda per ekenomian Negara. Contoh dukungan dari pemerintah adalah dorongan dari Kementerian Pariwisata kepada para pelaku usaha mikro kecil menengah untuk memanfaatkan kredit usaha rakyat (KUR) (republika.com, 2019). Penyaluran kredit KUR ini bertujuan untuk membantu UMKM dalam mengembangkan bisnis namun belum memiliki kecukupan dana.

Terdapat beberapa faktor yang memengaruhi penyaluran kredit perbankan. Penelitian sebelumnya yang dilakukan oleh Oktaviani dan Pangestuti (2012), menjelaskan bahwa faktor yang memengaruhi kredit perbankan adalah Dana Pihak Ketiga (DPK), Capital Adequacy Ratio (CAR) dan Sertifikat Bank Indonesia (SBI). Menurut Satria dan Subegti (2010), faktor yang memengaruhi penyaluran kredit perbankan adalah CAR, Return on Asset (ROA) dan SBI. Sementara menurut Barus dan $\mathrm{Lu}$ (2013), yang memengaruhi penyaluran kredit perbankan adalah Non Performing Loan (NPL). Terfokus pada penelitian terdahulu, maka beberapa faktor yang memengaruhi penyaluran kredit 
perbankan adalah DPK, CAR, ROA, NPL dan jumlah SBI.

Faktor pertama yang memengaruhi penyaluran kredit perbankan adalah DPK. DPK adalah salah satu sumber dana terbesar yang diperoleh dari masyarakat yang nantinya akan disalurkan kembali dalam bentuk kredit oleh perbankan (Sari dan Abudanti, 2016). DPK merupakan sumber dana dalam bentuk tabungan, deposito dan giro. Sebagai lembaga intermediasi, bank memiliki fungsi untuk menyalurkan kembali sumber dana yang didapat dari masyarakat dalam bentuk kredit. Menurut Oktaviani dan Pangestuti (2012), semakin besar DPK yang berhasil dihimpun maka akan semakin besar pula kredit yang disalurkan.

Faktor kedua adalah CAR. CAR merupakan rasio yang digunakan untuk mengukur tingkat modal terhadap total aktiva tertimbang menurut risiko (Barus dan $\mathrm{Lu}$, 2013). CAR adalah cerminan sisi permodalan (Putri dan Akmalia, 2016). CAR juga merupakan syarat penting dalam mendukung ekspansi kredit yang lebih besar (Satria dan Subegti, 2010). Menurut Sari dan Abudanti (2016) nilai CAR yang tinggi menunjukkan keadaan modal yang stabil sehingga akan meningkatkan kemampuan bank dalam menghadapi kerugian yang muncul dari penyaluran kredit. Kerugian yang mungkin timbul dari penyaluran kredit adalah adanya kredit bermasalah yang membuat bank gagal untuk mengembalikan dana deposan. Ketika bank memiliki kecukupan modal, maka bank tidak perlu khawatir ketika deposan akan mengambil kembali dana yang telah disimpan pada bank.

Faktor ketiga adalah ROA. ROA adalah indikator yang akan menunjukkan bahwa apabila rasio ini meningkat, maka aktiva yang dimiliki bank telah digunakan dengan optimal untuk memperoleh pendapatan (Oktaviani dan Pangestuti, 2012). Bank secara optimal dapat memanfaatkan asetnya untuk dikelola sehingga menghasilkan pendapatan yang salah satunya bersumber dari kredit. Menurut Satria dan Subegti (2010) ketika ROA memengaruhi penyaluran kredit, maka semakin tinggi tingkat keuntungan yang diperoleh, maka akan memotivasi bank untuk melakukan spesialisasi sektor pembiayaan. Dengan kata lain, bank akan mengelola aset dengan baik untuk menyalurkan kredit demi mendapatkan keuntungan yang tinggi. 
Faktor keempat adalah NPL. NPL merupakan kredit bermasalah yang dapat diartikan sebagai pinjaman yang mengalami kesulitan pelunasan akibat adanya faktor kesengajaan atau faktor eksternal di luar kemampuan debitur (Putri dan Akmalia, 2016). Yang dikategorikan bermasalah adalah jenis kredit dengan kolektibilitas kurang lancar, diragukan dan macet. Bank Indonesia selaku bank sentral memiliki kebijakan bahwa setiap bank wajib menekan jumlah nilai NPL di bawah lima persen. NPL akan berpengaruh negatif terhadap kredit perbankan apabila nilai NPL bank di atas lima persen. Menurut Putri dan Akmalia (2016), hal tersebut dikarenakan ketika nilai NPL semakin tinggi maka bank harus menyediakan cadangan modal yang lebih banyak padahal modal sangat berpengaruh terhadap besarnya ekspansi kredit.

Faktor kelima adalah jumlah SBI. Menurut Oktaviani dan Pangestuti (2012), SBI merupakan surat berharga dalam mata uang rupiah yang diterbitkan oleh Bank Indonesia sebagai pengakuan utang berjangka waktu pendek dan alternatif penempatan dana pada SBI digunakan bank untuk meminimalkan risiko kredit macet dengan tingkat risiko yang rendah. Meskipun penempatan dana pada SBI memiliki tingkat risiko yang rendah, namun jika semakin banyak jumlah likuiditas yang ditempatkan pada investasi SBI, maka akan menyebabkan semakin berkurangnya penyaluran kredit bank umum (Satria dan Subegti, 2010).

Berdasarkan fenomena yang telah dijelaskan, maka penulis bermaksud untuk melakukan penelitian kembali terhadap variabel-variabel yang telah diteliti tersebut. Variabel yang digunakan dalam penelitian ini adalah dana pihak ketiga, capital adequacy ratio (CAR), return on asset (ROA), non performing loan (NPL), dan jumlah Sertifikat Bank Indonesia (SBI). Pemilihan variabel DPK sebagai variabel independen dikarenakan DPK menjadi produk perbankan yang paling dikenal oleh masyarakat. Pemilihan variabel CAR dan ROA sebagai variabel independen penelitian dikarenakan kedua variabel tersebut akan menjelaskan bagaimana keadaan struktur modal dan profit yang dicapai oleh bank. Selanjutnya pemilihan variabel NPL sebagai variabel independen penelitian dikarenakan variabel tersebut akan menjelaskan sejauh 
mana cara bank untuk mengelola kredit yang diberikan agar tidak menjadi kredit yang bermasalah. Sementara pemilihan variabel jumlah SBI sebagai variabel independen penelitian dikarenakan masih sedikitnya penelitian yang menggunakan penempatan dana pada SBI sebagai variabel penelitian di mana pada beberapa penelitian sebelumnya masih menggunakan tingkat suku bunga Bank Indonesia. Tujuan dari penelitian ini adalah untuk mengetahui pengaruh DPK, CAR, ROA, NPL dan jumlah SBI terhadap penyaluran kredit perbankan baik secara simultan dan parsial. Objek penelitian ini adalah Bank umum milik negara (BUMN) yang terdaftar di BEI periode 2009-2018. Pemilihan bank BUMN sebagai objek penelitian karena bank BUMN merupakan bank yang paling diminati oleh masyarakat karena merupakan bank yang dimiliki oleh pemerintah sehingga rasa kepercayaan masyarakat meningkat. Belum lagi empat dari bank BUMN termasuk pada bank buku 4 menurut Otoritas Jasa Keuangan. Berdasarkan uraian di atas, maka penulis tertarik untuk memberi judul Pengaruh Kinerja Keuangan, DPK dan Jumlah SBI Terhadap Penyaluran Kredit Perbankan (Studi Pada
Bank BUMN Yang Terdaftar di BEI Periode 2009-2018).

\section{TINJAUAN TEORI DAN}

\section{PENGEMBANGAN HIPOTESIS}

\section{Bank}

Pengertian bank menurut UU No. 10 Tahun 1998 adalah badan usaha yang menghimpun dana dari masyarakat dalam bentuk simpanan dan menyalurkannya kepada masyarakat dalam rangka meningkatkan taraf hidup rakyat banyak. Sehingga dalam kegiatannya, bank berperan sebagai perantara antara pihak yang kelebihan dana dengan pihak yang kekurangan dana.

\section{Kredit}

Perbankan merupakan salah satu sektor penting dalam pembangunan negara. Dengan penyaluran kredit, bank dapat membantu sektor yang kekurangan dana sekaligus membantu pembangunan suatu negara. Menurut Barus dan Lu (2013) kredit adalah kesepakatan pinjam-meminjam antara bank dengan pihak lain dalam jangka waktu tertentu yang mewajibkan pihak peminjam untuk melunasi hutang beserta dengan jumlah bunga. 
Diperlukan perencanaan penyaluran kredit yang matang agar penyaluran kredit dapat tepat sasaran. Nantinya penyaluran kredit tidak hanya terpaku pada sektor yang akan dibiayai, namun harus sesuai dengan tujuan bank. Fungsi perencanaan kredit menurut Taswan (2010) adalah "sebagai pengawasan agar pemberian kredit sesuai dengan rencana, untuk mengurangi ketidakpastian di masa yang akan datang, sebagai pedoman untuk melaksanakan bisnis dan untuk menentukan segmentasi pasar".

Bank dalam melakukan perhitungan penyaluran kredit dibatasi oleh batas maksimum pemberian kredit (BMPK). BMPK merupakan batas maksimal kredit yang diberikan bank kepada debitur baik perorangan atau kelompok usaha. Apabila tidak ada pembatasan penyaluran kredit, maka akan memungkinkan bank memberikan kredit dengan jumlah yang besar lalu akan timbul masalah baru yaitu kredit yang bermasalah. Sehingga tujuan pembatasan kredit yang diberikan kepada debitur adalah untuk membatasi risiko kredit bermasalah (Firdaus dan Ariyanti, 2004). Menurut Taswan (2010, 311) terdapat lima prinsip perkreditan yang digunakan bank dalam pemberian kredit: (1) Character: sifat, moral, dan watak dari debitur untuk tanggung jawab dalam membayar kewajibannya; (2) Capacity: kemampuan debitur dalam menghasilkan suatu laba penghasilan dari usaha untuk melunasi kewajibannya; (3) Capital: jumlah modal yang dimiliki debitur. Semakin besar modal yang dimiliki maka akan mengurangi kemungkinan risiko debitur gagal membayar kewajibannya; (4) Collateral: jaminan atas kredit yang diterima calon debitur. Bank memerlukan jaminan apabila debitur berisiko gagal membayar kewajiban. Jaminan yang dianggap aman apabila mampu meng - cover $120 \%$ dari total kredit; (5) Condition of economic: kondisi makro yang dapat memengaruhi bisnis debitur.

Selanjutnya menurut Kasmir (2008) terdapat dua jenis kredit dilihat dari sisi kegunaannya. Pertama adalah kredit investasi. Kredit Investasi merupakan kredit yang digunakan untuk keperluan perluasan usaha. Yang kedua adalah kredit modal kerja. Kredit ini digunakan untuk keperluan menambah produksi dalam kegiatan operasional. Rumus penyaluran adalah: 
$\mathrm{Y}=\mathrm{Ln}$ (jumlah kredit yang disalurkan)

\section{Sumber Dana Bank}

Bank memerlukan sumber dana yang paling cepat untuk diproses dalam menjaga likuiditas. Menurut Kasmir (2008) sumber dana bank adalah usaha bank dalam memperoleh dana untuk membiayai kegiatan operasional lalu terdapat tiga jenis sumber dana bank yaitu sumber dana dari bank sendiri, sumber dana dari masyarakat luas dan sumber dana dari lembaga lain.

Sumber dana dari masyarakat atau biasa disebut dana pihak ketiga merupakan sumber dana yang paling mudah dicari karena banyak tersedia di masyarakat. Dana pihak ketiga (DPK) adalah dana-dana yang dihimpun dari masyarakat berupa tabungan, deposito, dan giro (Febrianto dan Muid, 2013). Dana yang dihimpun akan digunakan bank untuk melakukan pendanaan aktivitas operasional. Semakin banyak dana yang dihimpun maka akan menunjukan semakin besar pula rasa kepercayaan masyarakat terhadap bank. Menurut Kasmir (2008), kegiatan penghimpun DPK dibagi ke dalam tiga jenis yaitu simpanan giro (demand deposit), simpanan tabungan (saving deposit) dan simpanan deposito (time deposit). Maka jika diformulasikan menjadi:

$$
\begin{aligned}
& \mathrm{DPK}=\text { simpanan giro }+ \text { simpanan tabungan }+ \\
& \text { simpanan deposito }
\end{aligned}
$$

\section{Investasi Sekuritas}

Investasi sekuritas atau investasi surat berharga menjadi alternatif yang dilakukan bank untuk menyalurkan likuiditas. Penempatan dana untuk menyalurkan likuiditas bisa dilakukan dengan cara penempatan dana pada Sertifikat Bank Indonesia (SBI). Menurut Taswan (2010), SBI adalah surat berharga dalam mata uang rupiah yang diterbitkan oleh Bank Indonesia sebagai pengakuan utang jangka pendek dengan sistem diskonto. Penempatan dana pada SBI memiliki risiko yang rendah (Oktaviani dan Pangestuti, 2012). Hal ini dikarenakan karena SBI memiliki kepastian pembayaran sesuai kesepatakan pada saat lelang (Taswan, 2010) serta menurut Fahmi (2014) tingkat suku bunga dan Bank Indonesia sudah menjadi jaminan kuat bahwa tingkat pengembalian akan selalu diperoleh serta sulit untuk Bank Indonesia akan bangkrut. Dengan penempatan dana yang memiliki risiko rendah, manajemen bank menjadikan penempatan dana pada SBI 
sebagai alternatif untuk meminimalkan risiko kredit macet (Oktaviani dan Pangestuti, 2012).

\section{Laporan Keuangan}

Laporan keuangan adalah laporan yang menunjukan kondisi keuangan perusahaan dalam satu periode tertentu (Kasmir, 2015). Setiap perusahaan yang terdaftar di BEI wajib untuk menyampaikan informasi laporan keuangan secara berkala. Hal ini diatur oleh surat keputusan direksi PT. Bursa Efek Indonesia Nomor KEP - 00059/BEI/07/2019. Nantinya laporan keuangan disampaikan sebagai bagian dari laporan tahunan perusahaan.

\section{Kinerja Keuangan}

Kinerja keuangan merupakan dasar untuk melakukan pengukuran kinerja yang pengukurannya dapat menggunakan laporan keuangan. Manfaat dari pengukuran kinerja adalah untuk mengukur prestasi yang telah diperoleh suatu organisasi, untuk menilai pencapaian per departemen dalam memberikan kontribusi bagi perusahaan, sebagai dasar penentuan strategi perusahaan untuk masa yang akan datang, sebagai petunjuk dalam pengambilan keputusan dan sebagai dasar penentuan kebijaksanaan penanaman modal agar dapat meningkatkan efisiensi dan produktivitas perusahaan (Sujarweni, 2017).

\section{Rasio Solvabilitas Bank}

Menurut Kasmir (2015), rasio solvabilitas bank merupakan ukuran kemampuan dalam mencari sumber dana untuk membiayai kegiatannya. Rasio solvabilitas bank adalah capital adequacy ratio (CAR). CAR merupakan rasio yang digunakan untuk melihat kinerja bank dari sisi permodalan. Hal ini dijelaskan oleh Barus dan $\mathrm{Lu}$ (2013) yang berpendapat bahwa CAR adalah rasio yang digunakan untuk melihat tingkat modal terhadap total aktiva tertimbang menurut risiko (ATMR). Menurut Taswan (2010), modal bank adalah dana yang ditempatkan oleh pemilik dalam rangka pendirian badan usaha yang digunakan untuk kegiatan usaha bank serta untuk memenuhi peraturan otoritas yang berlaku. Menurut POJK Nomor 11/POJK.03/2016 tentang Kewajiban Penyediaan Modal Minimum Bank Umum, modal minimum CAR adalah delapan persen. Berikut adalah rumus CAR:

$C A R=\frac{\text { Modal }}{A T M R} \times 100$ 


\section{Rasio Profitabilitas Bank}

Rasio profitabilitas bank merupakan rasio yang digunakan untuk mengukur tingkat efisiensi usaha dan profitabilitas yang dicapai oleh bank. Selain itu rasio profitabilitas juga berfungsi untuk menilai tingkat efektivitas manajemen perusahaan (Kasmir, 2015). Salah satu rasio profitabilitas bank adalah Return on asset (ROA). ROA merupakan rasio untuk mengukur kemampuan bank dalam memperoleh keuntungan (Prihartini dan Dana, 2018). Dari menjalankan peran sebagai lembaga intermediasi bank akan memperoleh pendapatan bunga. Semakin tinggi nilai ROA maka akan menunjukkan telah optimalnya cara bank dalam mengelola aktiva untuk menyalurkan kredit dan nantinya bank akan mendapatkan pendapatan dari bunga pinjaman (Putri dan Akmalia, 2016). Berikut adalah rumus ROA:

$$
R O A=\frac{\text { Laba sebelum pajak }}{\text { Total asset }} \times 100 \%
$$

\section{Rasio Likuiditas Bank}

Rasio likuiditas bank adalah rasio yang digunakan untuk mengukur seberapa likuid suatu bank dalam melayani nasabahnya. Jasa atau layanan bank salah satunya adalah pengiriman (transfer) atau penarikan uang tunai. Apabila bank tidak dapat menyediakan dana secara cepat, maka nasabah akan mengalami krisis kepercayaan. Salah satu penyebab perusahaan tidak mampu membayar kewajibannya adalah karena manajemen perusahaan tidak menghitung rasio keuangan secara menyeluruh sehingga perusahaan tidak mengetahui keadaan sebenarnya di mana hutang lebih besar dibanding dengan harta lancarnya. Untuk menghindari perusahaan tidak mampu membayar kewajiban pada saat jatuh tempo, rasio likuiditas berfungsi untuk mengukur kemampuan perusahaan dalam memenuhi kewajiban (utang) pada saat ditagih (Kasmir, 2015).

Salah satu rasio likuiditas bank adalah non -performing loan (NPL). NPL merupakan menghitung total kredit bermasalah dengan total kredit yang disalurkan oleh bank (Putri dan Akmalia, 2016). Kredit yang dikatakan bermasalah adalah kredit dengan kolektibilitas kurang lancar, diragukan dan macet. Kolektibilitas kredit yang semakin meningkat akan berdampak negatif kepada bank. Hal ini dikarenakan karena bank harus menyediakan cadangan modal yang lebih besar yang di 
mana pada akhirnya modal bank akan ikut terkikis dan memengaruhi penyaluran kredit (Oktaviani dan Pangestuti, 2012). Berikut adalah rumus NPL:

$$
N P L=\frac{\text { Kredit bermasalah }}{\text { Total Kredit }} \times 100
$$

\section{Kerangka Konseptual}

Berdasarkan penjelasan di atas, maka kerangka konseptual penelitian ini dijelaskan pada gambar 1. Adapun hipotesis penelitian ini adalah:

$H_{1}$ : DPK, CAR, ROA, NPL dan jumlah SBI memengaruhi secara simultan penyaluran kredit perbankan pada bank BUMN yang terdaftar di BEI periode 2009 - 2018 .

$H_{2}$ : DPK memengaruhi penyaluran kredit perbankan pada bank BUMN yang terdaftar di BEI periode $2009-2018$.

$H_{3}$ : CAR memengaruhi penyaluran kredit perbankan pada bank BUMN yang terdaftar di BEI periode $2009-2018$.

$H_{4}$ : ROA memengaruhi penyaluran kredit perbankan pada bank BUMN yang terdaftar di BEI periode $2009-2018$.

$H_{5}$ : NPL memengaruhi penyaluran kredit perbankan pada bank BUMN yang terdaftar di BEI periode $2009-2018$.

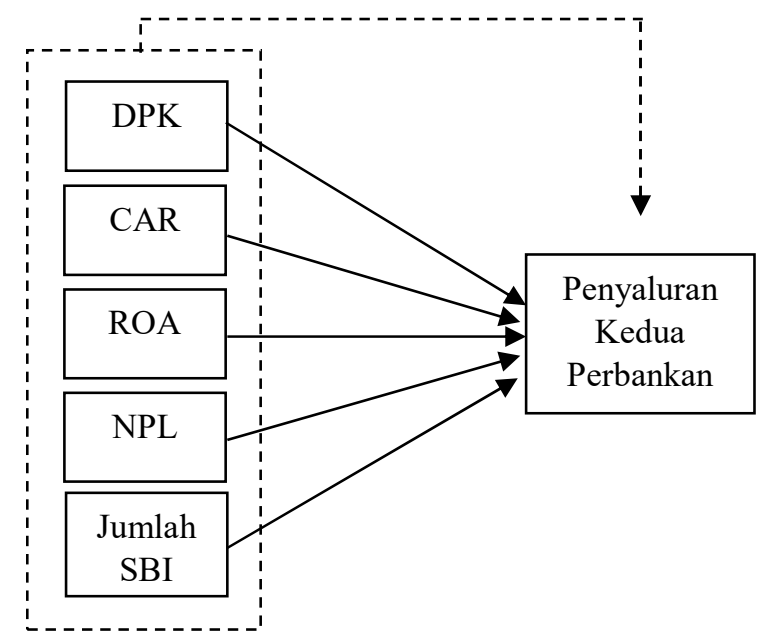

Gambar 1. Kerangka Konseptual

(Sumber : data diolah, 2019)

Keterangan gambar :

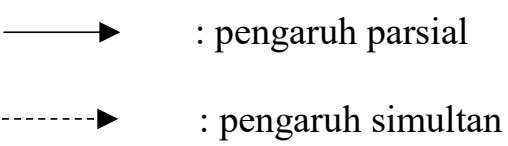

$H_{6}$ : Jumlah SBI memengaruhi penyaluran kredit perbankan pada bank BUMN yang terdaftar di BEI periode $2009-2018$.

\section{METODE RISET}

Penelitian ini menggunakan metode kuantitatif. Metode kuantitatif adalah sebuah metode ilmiah karena telah memenuhi kaidahkaidah ilmiah yaitu konkrit/empiris, obyektif, terukur, rasional dan sistematis serta data penelitian berupa angka-angka dan dianalisis menggunakan statistik (Sugiyono, 2017).

Variabel independen yang digunakan untuk penelitian ini adalah DPK, CAR, ROA, NPL dan jumlah SBI. Perhitungan mengenai 
semua variabel independen menggunakan

periode $\mathrm{t}-1$. Alasannya karena salah satu cara

bank dalam menghasilkan laba adalah dengan

pengalokasian dana dalam bentuk kredit yang

merujuk pada periode tahun sebelumnya.

Adapun variabel dependen pada penelitian ini

adalah penyaluran kredit perbankan.

Populasi dalam penelitian ini menggunakan Bank BUMN yang terdaftar di BEI periode 2009-2018. Purposive Sampling digunakan sebagai teknik sampling, sehingga diperoleh sampel 4 bank BUMN yang terdaftar di BEI periode 2009-2018.

Menurut Sujarweni (2014), analisis regresi merupakan analisis yang bertujuan untuk menguji pengaruh antara satu variabel dengan variabel lain. Terdapat dua macam regresi yaitu sederhana dan linear berganda. Keduanya dibedakan berdasarkan jumlah variabel independen yang diteliti. Berdasarkan hipotesis penelitian, maka analisis regresi linear berganda digunakan untuk menguji pengaruh variabel independen terhadap variabel dependen. Tingkat signifikansi yang digunakan adalah $10 \%$. Peneliti menggunakan regresi linear berganda karena penelitian menggunakan lebih dari dua variabel independen.
Sebelum melakukan analisis regresi linier berganda perlu dilakukan uji asumsi klasik untuk mengurangi kemungkinan kesalahan peramalan. Beberapa asumsi klasik yang harus dipenuhi adalah uji normalitas, uji heteroskedastisitas, uji multikolinearitas dan uji autokorelasi (Santoso, 2018).

Setelah lolos uji asumsi klasik, barulah dilaksanakan analisis regresi linier berganda untuk melakukan pengujian hipotesis menggunakan Uji F, Koefisien determinasi dan Uji t.

\section{HASIL PENELITIAN DAN}

\section{PEMBAHASAN}

\section{Uji Asumsi Klasik}

Hasil dari uji asumsi klasik pada penelitian ini menunjukkan bahwa model regresi berdistribusi normal dan memenuhi asumsi normalitas karena distribusi data menunjukkan distribusi yang normal. Selanjutnya model regresi terbebas dari heteroskedastisitas karena titik data tidak membuat pola naik ke kanan atas atau menurun ke kiri bawah melainkan menyebar dan tidak mengumpul hanya di satu sisi. Lalu model regresi tidak mengalami multikolinieritas hasil angka VIF pada semua 
variabel independen penelitian berada di antara angka satu sampai sepuluh. Dan yang terakhir model regresi tidak mengalami autokorelasi karena hasil Asymp.sig (2- tailed) lebih besar dari 0,1. Pada uji autokorelasi menggunakan metode uji Run test.

\section{Pengujian Hipotesis}

Uji F

Berdasarkan hipotesis penelitian, penelitian akan melakukan uji $\mathrm{F}$ atau uji simultan. Hasil penelitian akan menjelaskan mengenai 5 variabel independen yang akan memengaruhi atau tidak memengaruhi variabel dependen secara bersamaan. Hasil penelitian dijelaskan dalam tabel 1. Berdasarkan tabel 1, uji Anova atau uji $\mathrm{F}$ di dapat nilai $\mathrm{F}$ hitung sebesar 182,785 dan $\mathrm{F}$ tabel adalah 2,02. Karena nilai F hitung lebih besar daripada $\mathrm{F}$ tabel, maka $H_{0}$ ditolak. hipotesis penelitian $H_{1}$ diterima yang artinya DPK, CAR, ROA, NPL dan jumlah SBI memengaruhi secara simultan penyaluran kredit perbankan pada bank BUMN yang terdaftar di BEI periode 2009 - 2018.
Tabel 1. Uji F

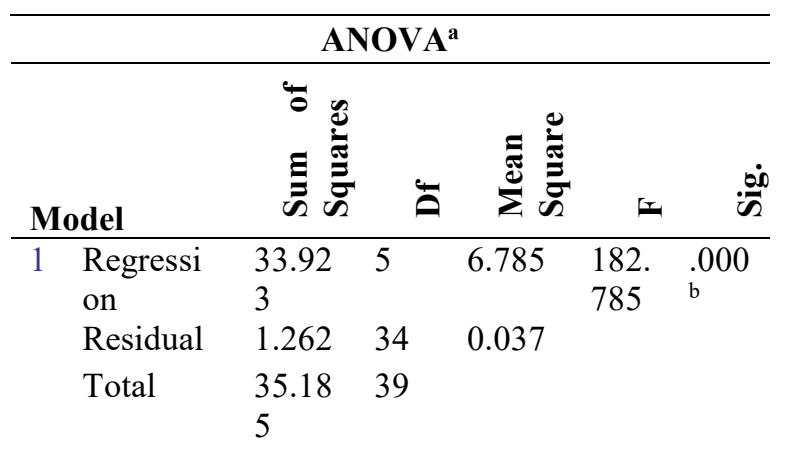

a. Dependent Variable: Kredit

b. Predictors: (Constant), SBI, NPL, CAR, DPK, ROA

Tabel 2. Koefisien Determinasi Model Summary ${ }^{\mathrm{b}}$

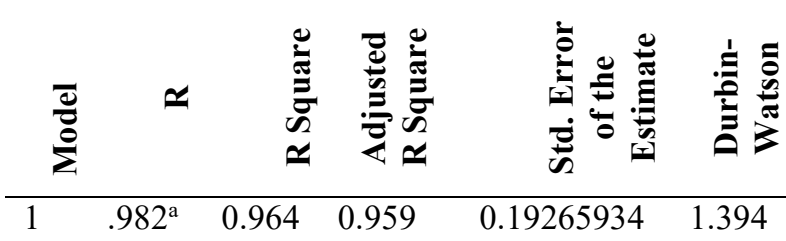

a. Predictors: (Constant), SBI, NPL, CAR, DPK, ROA

b. Dependent Variable: Kredit

\section{Koefisien Determinasi}

Hasil penelitian menjelaskan bahwa variabel dependen dapat dijelaskan oleh variabel independen. Angka $\mathrm{R}$ square menjelaskan nilai dari koefisien determinasi.

Berdasarkan tabel 2, angka $\mathrm{R}$ square adalah 0,964. Hal ini menyatakan bahwa varian variabel $\mathrm{Y}$ (penyaluran kredit perbankan) dapat dijelaskan oleh varian variabel $\mathrm{X}$ yang signifikan yaitu DPK dan CAR sebesar $96,4 \%$. Sedangkan sisanya yaitu $3,6 \%$ dijelaskan oleh variabel lain di luar 
penelitian ini. Ada pula angka adjusted $R$ square sebesar 0,959. Angka ini mendekati angka satu yang menandakan kemampuan variabel $\mathrm{X}$ dalam menjelaskan variabel $\mathrm{Y}$ tidak terbatas.

Uji $t$

Berdasarkan hipotesis penelitian, penelitian ini akan melakukan uji $\mathrm{t}$ atau uji parsial. Di mana hasil penelitian akan menjelaskan pengaruh masing-masing lima variabel independen terhadap variabel dependen. Hasil pengujian terhadap model regresi menghasilkan model sebagai berikut:

$\mathrm{Y}=1,297+0,948 \mathrm{DPK}+0,032 \mathrm{CAR}-0,039$

ROA - 0,050 NPL - 0,000000000000006136 jumlah SBI.

Hasil penelitian uji t dapat dilihat pada tabel 3. Pada hasil uji $t$, didapat $t$ hitung dan $t$ tabel untuk setiap variabel independen. Nilai $\mathrm{t}$ hitung variabel DPK yaitu 22,440. Sementara itu, nilai $\mathrm{t}$ tabelnya yaitu 1,69092 . Karena $\mathrm{t}$ hitung lebih besar daripada $\mathrm{t}$ tabel, maka $H_{0}$ ditolak. Dengan kata lain, hipotesis penelitian $\mathrm{H}_{2}$ diterima yaitu DPK memengaruhi penyaluran kredit pada Bank BUMN yang terdaftar di BEI periode 20092018.
Nilai t hitung variabel CAR yaitu 2,356 sementara nilai t tabelnya yaitu 1,69092. Karena t hitung lebih besar daripada $t$ tabel maka $H_{0}$ ditolak. Jadi hipotesis penelitian $H_{3}$ diterima yaitu CAR memengaruhi penyaluran kredit pada Bank BUMN yang terdaftar di BEI periode 2009-2018.

Selanjutnya untuk memperkuat hasil penelitian, dijelaskan pula hasil t hitung dan $\mathrm{t}$ tabel dari tiap variabel independen yang berpengaruh. Nilai t hitung variabel DPK yaitu 28,198, sementara nilai $\mathrm{t}$ tabelnya yaitu 1,68709. Karena t hitung lebih besar daripada $t$ tabel, maka $H_{0}$ ditolak. Jadi hipotesis penelitian $\mathrm{H}_{2}$ diterima yaitu DPK memengaruhi penyaluran kredit pada Bank BUMN yang terdaftar di BEI periode 20092018.

Nilai t hitung variabel CAR adalah 2,721 sementara $\mathrm{t}$ tabelnya adalah 1,68709 . Karena $\mathrm{t}$ hitung lebih besar daripada $\mathrm{t}$ tabel maka $H_{0}$ ditolak. Jadi hipotesis penelitian $H_{3}$ diterima yaitu CAR memengaruhi penyaluran kredit pada Bank BUMN yang terdaftar di BEI periode 2009-2018. 
Tabel 4. Uji t

Coefficients $^{a}$

\begin{tabular}{|c|c|c|c|c|c|c|c|c|}
\hline \multicolumn{2}{|c|}{ Model } & \multicolumn{2}{|c|}{$\begin{array}{l}\text { Unstandardized } \\
\text { Coefficients }\end{array}$} & \multirow[t]{2}{*}{$\begin{array}{l}\text { Standardized } \\
\text { Coefficients }\end{array}$} & \multirow[t]{2}{*}{$\mathbf{t}$} & \multirow[t]{2}{*}{ Sig. } & \multicolumn{2}{|c|}{$\begin{array}{l}\text { Collinearity } \\
\text { Statistics }\end{array}$} \\
\hline & & B & $\begin{array}{l}\text { Std. } \\
\text { Error }\end{array}$ & & & & Tolerance & VIF \\
\hline \multirow[t]{6}{*}{1} & (Constant) & 1.297 & 1.353 & & 0.959 & 0.345 & & \\
\hline & DPK & 0.948 & 0.042 & 0.941 & 22.440 & 0.000 & 0.601 & 1.665 \\
\hline & CAR & 0.032 & 0.013 & 0.088 & 2.356 & 0.024 & 0.763 & 1.311 \\
\hline & ROA & -0.039 & 0.057 & -0.046 & -0.689 & 0.496 & 0.233 & 4.297 \\
\hline & NPL & -0.050 & 0.062 & -0.048 & -0.804 & 0.427 & 0.297 & 3.364 \\
\hline & SBI & $\begin{array}{l}6.136 \mathrm{E}- \\
15\end{array}$ & 0.000 & 0.036 & 0.827 & 0.414 & 0.549 & 1.822 \\
\hline
\end{tabular}

a. Dependent Variable: Kredit

Tabel 5. Uji t DPK dan CAR

Coefficients $^{\mathbf{a}}$

\begin{tabular}{|c|c|c|c|c|c|c|c|}
\hline \multirow[b]{2}{*}{ Mod } & \multicolumn{2}{|c|}{$\begin{array}{c}\text { Unstandardized } \\
\text { Coefficients } \\
\text { Std. }\end{array}$} & \multirow{2}{*}{$\begin{array}{c}\text { Standardized } \\
\text { Coefficients } \\
\text { Beta }\end{array}$} & \multirow[b]{2}{*}{$\mathbf{T}$} & \multirow[b]{2}{*}{ Sig. } & \multicolumn{2}{|c|}{$\begin{array}{c}\text { Collinearity } \\
\text { Statistics }\end{array}$} \\
\hline & B & $\begin{array}{l}\text { Std. } \\
\text { Error }\end{array}$ & & & & Tolerance & VIF \\
\hline 1 (Constant) & 0.855 & 1.069 & & 0.799 & 0.429 & & \\
\hline DPK & 0.954 & 0.034 & 0.946 & 28.198 & 0.000 & 0.882 & 1.133 \\
\hline CAR & 0.033 & 0.012 & 0.091 & 2.721 & 0.010 & 0.882 & 1.133 \\
\hline
\end{tabular}

a. Dependent Variable: Kredit

penelitian ini juga serupa dengan hasil

\section{Pembahasan}

Pengaruh DPK, CAR, ROA, NPL dan Jumlah

SBI Terhadap Penyaluran Kredit Perbankan

Secara Simultan

Berdasarkan hasil pengolahan data, didapat hasil bahwa DPK, CAR, ROA, NPL dan jumlah SBI memengaruhi penyaluran kredit perbankan secara simultan. Hasil penelitian Oktaviani dan Pangestuti (2012).

Pengaruh DPK Terhadap Penyaluran Kredit Perbankan

Berdasarkan hasil pengolahan data, didapat bahwa DPK memengaruhi penyaluran kredit perbankan. Menurut Febrianto dan Muid (2013), semakin banyak DPK yang berhasil dihimpun, maka akan semakin 


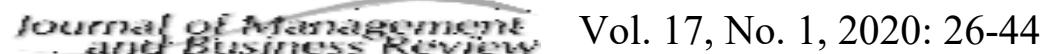

meningkatkan kemampuan bank dalam menyalurkan kredit kepada masyarakat yang membutuhkan dana. Sementara menurut Sari dan Abudanti (2016), DPK merupakan sumber dana terbesar yang diperoleh perbankan sehingga ketika DPK semakin besar maka akan semakin besar pula penyaluran kredit perbankan.

Pengaruh CAR Terhadap Penyaluran Kredit Perbankan

Berdasarkan hasil pengolahan data, didapat hasil bahwa CAR memengaruhi penyaluran kredit perbankan. Menurut Satria dan Subegti (2010), CAR merupakan syarat penting dalam mendukung ekspansi kredit yang lebih besar. Nantinya dengan besarnya nilai CAR akan mencerminkan besarnya modal yang dimiliki bank sehingga dengan modal yang cukup akan meningkatkan kemampuan bank dalam menyalurkan kreditnya (Putri dan Akmalia, 2016). Menurut Sari dan Abudanti (2016) nilai CAR yang tinggi menunjukan keadaan modal yang stabil sehingga akan meningkatkan kemampuan bank dalam menghadapi kerugian yang muncul dari penyaluran kredit.
Pengaruh ROA Terhadap Penyaluran Kredit Perbankan

Berdasarkan hasil pengolahan data, didapat hasil bahwa ROA tidak memengaruhi penyaluran kredit perbankan. Menurut Febrianto dan Muid (2013), alasan ROA tidak memengaruhi penyaluran kredit perbankan dikarenakan nilai perolehan laba bank tidak menjadi patokan bank untuk menyalurkan kredit lebih banyak. Namun menurut Putri dan Akmalia (2016), dengan perolehan laba yang tinggi dari kegiatan penyaluran kredit, maka bank akan terus menyalurkan kreditnya agar mendapatkan laba yang tinggi. Oleh karena itu, jika nilai ROA tinggi akan meningkatkan penyaluran kredit.

Pengaruh NPL Terhadap Penyaluran Kredit Perbankan

Berdasarkan hasil pengolahan data, didapat hasil bahwa NPL tidak memengaruhi penyaluran kredit perbankan. Menurut Febrianto dan Muid (2013), alasan NPL tidak memengaruhi penyaluran kredit perbankan dikarenakan faktor kredit macet tentunya tidak lepas dari aktivitas utama bank berupa penyaluran kredit. Namun apabila nilai NPL meningkat dan masih dalam batas wajar, 
Pengaruh Kinerja Keuangan, DPK dan jumlah SBI...(Tieka Trikartika G \& Sasdalia Nova D)

maka bank akan tetap meningkatkan penyaluran kreditnya karena bank masih merasa mampu untuk mengatasi permasalahan kredit macet. Namun menurut Barus dan Lu (2013), NPL mencerminkan risiko kredit. Semakin tinggi tingkat NPL, maka akan semakin besar risiko kredit yang ditanggung oleh pihak bank. Apabila bank tidak dapat menjaga risiko kreditnya, maka cara untuk menjaga risiko kredit adalah dengan mengurangi kredit yang disalurkan.

Pengaruh Jumlah SBI Terhadap Penyaluran Kredit Perbankan

Berdasarkan hasil pengolahan data, didapat hasil bahwa jumlah SBI tidak memengaruhi penyaluran kredit perbankan. Hasil ini tidak serupa dengan hasil penelitian sebelumnya yang mengatakan bahwa meningkatnya dana yang disalurkan dalam bentuk SBI dapat menurunkan jumlah kredit yang disalurkan. Hal ini dikarenakan manajemen bank akan melakukan usaha untuk meminimalkan risiko kredit dengan melakukan investasi pada Sertifikat Bank Indonesia (Oktaviani dan Pangestuti, 2012).

\section{KESIMPULAN DAN SARAN}

Kesimpulan

DPK, CAR, ROA, NPL dan jumlah SBI memengaruhi secara simultan penyaluran kredit perbankan pada bank BUMN yang terdaftar di BEI periode 2009 - 2018. Selanjutnya secara parsial DPK dan CAR memengaruhi penyaluran kredit perbankan pada bank BUMN yang terdaftar di BEI periode 2009 - 2018. Sementara ROA, NPL dan jumlah SBI secara parsial tidak memengaruhi penyaluran kredit perbankan pada bank BUMN yang terdaftar di BEI periode $2009-2018$.

\section{Saran}

Diharapkan penelitian selanjutnya menggunakan objek penelitian serta populasi dan sampel yang lebih banyak agar memperoleh hasil yang lebih akurat. Lalu disarankan untuk Bank Indonesia selaku bank sentral dapat membuat kebijakan mengenai batas minimal DPK yang harus dihimpun oleh bank agar penyaluran kredit perbankan dapat terjaga dan tidak mengalami penurunan. Sementara saran untuk bank BUMN adalah dapat menghimpun dana pihak ketiga yang bersumber dari masyarakat serta menambah modal bank lebih banyak lagi. Hal ini 
fournal of Marsiggment Vol. 17, No. 1, 2020: 26-44

dikarenakan hasil dari penelitian yang

menjelaskan bahwa DPK dan CAR

memengaruhi penyaluran kredit perbankan.

Dengan meningkatkan DPK dan CAR, maka

akan meningkatkan juga penyaluran kredit

perbankan. 
Pengaruh Kinerja Keuangan, DPK dan jumlah SBI...(Tieka Trikartika G \& Sasdalia Nova D)

\section{DAFTAR PUSTAKA}

Alamsyah, I. E. (2019). Kemenpar Dorong UMKM Pariwisata Manfaat Kredit KUR. Retrieved from https://www.republika.co.id/berita/ekonomi/keuangan/19/02/10/pmp09f349-kemenpar-dorongumkm-pariwisata-manfaatkan-kur

Barus, A. C., \& Lu, M. (2013). Pengaruh Spread Tingkat Suku Bunga dan Rasio Keuangan Terhadap Penyaluran Kredit UMKM Pada Bank Umum di Indonesia. Jurnal Wira Ekonomi Vol.3, No. 1 April, 11-20.

Fahmi, I. (2014). Bank dan Lembaga Keuangan Lainnya Teori dan Aplikasi. Bandung: Alfabeta.

Febrianto, D. F., \& Muid, D. (2013). Analisis Pengaruh DPK, LDR, NPL, CAR dan BOPO Terhadap Penyaluran Kredit (Studi Pada Bank Umum Yang Terdaftar di BEI Periode Tahun 2009 2012). Diponegoro Journal Of Accounting Vol.2 No.3, 1-11.

Firdaus, R., \& Ariyanti, M. (2004). Manajemen Perkreditan Bank Umum : Teori, Masalah, Kebijakan dan Aplikasinya Lengkap dengan Analisis Kredit. Bandung: Alfabeta.

Kasmir. (2008). Dasar - Dasar Perbankan. Jakarta: PT. Raja Grafindo.

Kasmir. (2015). Analisis Laporan Keuangan. Jakarta: Rajawali Pers.

Oktaviani, \& Pangestuti, I. R. (2012). Pengaruh DPK, CAR, ROA, NPL dan Jumlah SBI Terhadap Penyaluran Kredit Perbankan (Studi Pada Bank Umum Go Public di Indonesia Periode 2008 2011). Diponegoro Journal Of Management Vol. 1, No. 1, 430-438.

Otoritas Jasa Keuangan . Statistik Perbankan Indonesia

(n.d.). Peraturan Otoritas Jasa Keuangan No 10/POJK.03/2016 Tentang Kewajiban Penyediaan Modal Minimum Bank Umum.

Prihartini, S., \& Dana, I. M. (2018). Pengaruh CAR, NPL dan ROA Terhadap Penyaluran Kredit Usaha Rakyat (Studi Kasus pada PT. Bank Rakyat Indonesia Tbk). e-jurnal Manajemen Unud Vol. 7, No.3, 1168-1194. 
Putra, I. B., \& Wirathi, I. (2014). Pengaruh LDR, BI Rate, CAR, NPL Terhadap Penyaluran Kredit UMKM di Bank Umum Provinsi Bali Periode 2004.I - 2012.IV. E-jurnal Ekonomi Pembangunan Universitas Udayana Vol. 3 No. 12, 603-612.

Putri, Y. M., \& Akmalia, A. (2016). Pengaruh CAR, NPL, ROA dan LDR Terhadap Penyaluran Kredit Pada Perbankan (Studi Pada Perusahaan Perbankan Yang Listed DI Bursa Efek Indonesia Periode 2011-2015). Balance Vol.XIII No.2 Juli, 82-93.

Santoso, S. (2018). Menguasai Statistik dengan SPSS 25. Jakarta: PT. Elex Media Komputindo.

Sari, N. M., \& Abudanti, N. (2016). Pengaruh DPK, ROA, Inflasi dan Suku Bunga SBI Terhadap Penyaluran Kredit Pada Bank Umum. E-jurnal Manajemen Unud Vol.5, No.1 , 7156-7184.

Satria, D., \& Subegti, R. (2010). Determinasi Penyaluran Kredit Bank Umum di Indonesia Periode 2006 - 2009. Jurnal Keuangan dan Perbankan Vol. 14, No. 3 September, 415-424.

Simorangkir, E. (2017). 7 Bank Akan Keroyokan Biayai LRT Jabodetabek. Retrieved from https://finance.detik.com/infrastruktur/d-3777604/7-bank-akan-keroyokan-biayai-lrt-jabodebek

Sugiyono. (2017). Metode Penelitian Kuantitatif, Kualitatif dan R\&D. Bandung: Alfabeta.

(n.d.). Surat keputusan direksi PT. Bursa Efek Indonesia Nomor KEP - 00059/BEI/07/2019.

Sujarweni, V. W. (2017). Analisis Laporan Keuangan : Teori, Aplikasi dan Hasil Penelitian. Yogyakarta: Pustaka Baru Press.

Taswan. (2010). Manajemen Perbankan : Konsep, Teknik, dan Aplikasi. Yogyakarta: UPP STIM YKPN.

(n.d.). Undang - Undang No. 10 Tahun 1998. 